\title{
De ontwikkeling van de controller in Nederland
}

\section{Een verkenning van de praktijk}

\section{Femke Riedijk, Sandra Tillema en Eric Moen ${ }^{1}$}

SAMENVATTING De afgelopen jaren wordt in de literatuur veel aandacht besteed aan de veranderende rol en functie van de controller. Opvallend is dat hierbij voornamelijk wordt ingegaan op visies ten aanzien van de gewenste of verwachte rol en functie van de controller in de toekomst. Er is echter betrekkelijk weinig aandacht voor de vraag of de in de literatuur gesuggereerde ontwikkeling in de praktijk ook daadwerkelijk plaatsvindt. Op basis van een door de auteurs uitgevoerd praktijkonderzoek bij verschillende organisatietypen, wordt geconcludeerd dat de rol van de controller in de Nederlandse praktijk zich voorlopig niet in die mate heeft ontwikkeld als in de literatuur wordt gesuggereerd.

\section{Inleiding}

De veranderingen in de wereld om ons heen volgen elkaar in hoog tempo op. Dit is mede het gevolg van het feit dat steeds meer sprake is van sterke - en vooral ook internationale - concurrentie op inkoop- en afzetmarkten en van snelle ontwikkelingen op het gebied van de technologie - waaronder de informatietechnologie. Deze veranderingen hebben uiteraard ook consequenties voor de rol en de functie van de controller. In zowel de internationale als de Nederlandse literatuur is de afgelopen jaren dan ook veel aandacht besteed aan (veranderingen in) de rol en de functie van de controller in de toekomst ${ }^{2}$. De

Drs. F.L. Riedijk is als bedrijfseconoom afgestudeerd aan de Rijksuniversiteit Groningen.

Drs. S. Tillema is universitair docent aan de Economische Faculteit van de Rijksuniversiteit Groningen.

Drs. E. Moen is werkzaam als senior consultant bij KPMG Advisory in Zwolle. opvattingen over hoe deze zich zullen gaan ontwikkelen, lopen uiteen. Aan de ene kant is er een optimistisch beeld waarin een steeds bredere functie en meer leidende rol voor de controller is weggelegd. Aan de andere kant is er een pessimistisch beeld waarin wordt betwijfeld of de controller in de toekomst nog een rol te vervullen heeft.

Opvallend is dat een groot deel van de literatuur waarin het optimistische beeld aan de orde komt, slechts ingaat op visies die bestaan omtrent de gewenste of verwachte rol en functie van de controller in de toekomst. Er wordt gesproken over een verbreding van de controllersfunctie, waarbij de controller zich ontwikkelt van een ondersteuner die aan de zijlijn zijn invloed probeert uit te oefenen naar een medestrategiebepaler die deel uitmaakt van het management. Men kan zich echter afvragen of de in de literatuur gesuggereerde ontwikkeling van de rol en de functie van de controller in de praktijk ook daadwerkelijk plaatsvindt. In de internationale literatuur wordt dit laatste inderdaad deels bevestigd. Granlund en Lukka (1998) laten bijvoorbeeld zien dat er in Finland in steeds meer organisaties sprake is van een controller die niet alleen de financiële positie van de organisatie in het oog houdt, maar die ook optreedt als adviseur richting het management in beslissingsprocessen. In andere landen doet een dergelijke ontwikkeling zich in nog sterkere mate voor. Zo signaleren Burns e.a. $(1996)^{3}$ en IMA (1996) dat in respectievelijk het Verenigd Koninkrijk en de Verenigde Staten de beslissingsondersteunende en adviserende rol van de controller steeds meer de administratieve en controlerende rol verdringt. In geen van deze onderzoeken hebben de rol en de functie van de controller zich echter al in die mate ontwikkeld als in de literatuur wordt gesuggereerd.

De Nederlandse literatuur over de rol en de functie van de controller in de praktijk is beperkt. Toch zijn enkele bevindingen op dit terrein het vermelden waard. Zo concludeert Van Helden (1998), op basis 
van in personeelsadvertenties geformuleerde eisen, dat Nederlandse werkgevers op dit moment in het algemeen nog geen behoefte lijken te hebben aan brede controllers. Van Helden en Rutten (2000) komen eveneens op basis van een onderzoek naar personeelsadvertenties - tot een vergelijkbare conclusie: de taken en verantwoordelijkheden van Nederlandse non-profitcontrollers hebben primair betrekking op de meer traditionele taken, namelijk verzorging van de planning- en controlcyclus en verschaffing van managementinformatie. Van der Meer-Kooistra (1998), ten slotte, concludeert - op basis van gesprekken met vijf controllers - dat de rol en de functie van de controller tussen organisaties varieert. Deze variatie blijkt onder andere verband te houden met de ontstaansreden van de controllersfunctie en met persoonsgebonden kenmerken.

Omdat onze kennis van de feitelijke rol en functie van de Nederlandse controller beperkt is, zal in dit artikel een aanzet worden gegeven tot een meer systematische ontwikkeling van dit onderzoeksgebied. Het artikel zal zich daarbij beperken tot de rol van de controller in het planning- en controlproces. In de literatuur wordt in het algemeen niet helder aangegeven wat het onderscheid is tussen enerzijds de rol en anderzijds de functie van de controller. Wij zullen onder de rol van de controller de wijze verstaan waarop de controller opereert richting de overige leden van de organisatie: administreert hij wat zij doen, controleert hij wat zij doen, adviseert en ondersteunt hij hen, of denkt hij met hen mee. De functie van de controller kan dan worden gezien als de reikwijdte van zijn takenpakket: houdt hij zich alleen bezig met de administratie, of wordt hij daarnaast ook betrokken bij de planning en control en de besluitvorming, of bij zaken als het ontwikkelen van informatiesystemen en het bepalen van de strategie. Hoewel er bij dit onderscheid tussen de rol en de functie van de controller sprake is van een zekere mate van overlap, biedt het wel de mogelijkheid om te kijken naar de rol van de controller bij de vervulling van een deel van zijn takenpakket. Zo kan er bijvoorbeeld worden gekeken of de controller bij de strategiebepaling een adviserende of een meedenkende rol heeft.

In het artikel wordt rekening gehouden met de mogelijkheid dat alleen voor bepaalde typen organisaties een meeromvattende rol van de controller waarschijnlijk is. Hiertoe zal de mogelijke rol van de controller in vijf organisatietypen worden onderzocht. Deze organisatietypen worden gedefinieerd aan de hand van Mintzbergs theorie over de structuur van organisaties. Voor elk van de door Mintzberg gedefi- nieerde typen zal een theoretische verwachting worden geformuleerd voor de rol van de controller. Vervolgens zal aan de hand van een serie gesprekken met controllers van verschillende typen organisaties worden bekeken of de verwachte rol in overeenstemming is met de werkelijke rol.

Het artikel is als volgt opgebouwd. In paragraaf 2 worden de drie typen controllers besproken zoals deze regelmatig in de literatuur worden geschetst. Vervolgens komen in paragraaf 3 de mogelijke rollen aan de orde die de controller kan vervullen in het planning- en controlproces. In paragraaf 4 wordt ingegaan op de organisatietypen van Mintzberg en de invloed van de kenmerken van deze organisatietypen op de rol van de controller. In paragraaf 5 worden de resultaten van het praktijkonderzoek besproken. Het artikel wordt afgesloten met een discussie van de resultaten.

\section{Typen controllers}

Wanneer we de literatuur bestuderen, dan zien we dat twee controllersprofielen vaak tegenover elkaar worden gezet, namelijk de 'corporate policeman' en de 'business advocate'

\section{Corporate policeman}

Bij het type van de 'corporate policeman' staan de belangen van het topmanagement voorop. Het is de taak van de controller om overzicht en toezicht te houden. Ook is het zijn taak om regels en procedures vast te leggen en vervolgens scherp op de naleving ervan toe te zien. Centraal staat het intern afleggen van verantwoording: er wordt gekeken of wat gerealiseerd is in overeenstemming is met de normen. Dit type controller heeft dus een retrospectieve blik. Hij vervult vooral een administratieve, ten behoeve van het topmanagement controlerende rol (Jablonsky e.a., 1993; voor een samenvatting zie: Van Helden 1998, p. 19; Van der Meer-Kooistra, 1999, p. 82; Scapens, 1999, p. 645).

\section{Business advocate}

De 'business advocate' heeft een meer prospectieve blik. Dit type controller stelt zich primair op als serviceverlener van de interne participanten. Deze controller heeft kennis van de activiteiten en voelt zich betrokken bij de organisatie. De functie van dit type controller kan als breed worden aangemerkt. Kennis van zijn eigen discipline is belangrijk, maar daarnaast wordt ook van hem verwacht dat hij (enige) kennis van andere disciplines heeft. Zo denkt hij bijvoorbeeld mee over de manier waarop de producten het 
beste op de markt kunnen worden gepositioneerd en analyseert hij de risico's en de financiële consequenties. De controller vervult vooral een beslissingsondersteunende en stimulerende rol. Hij vervult deze rol voor alle geledingen van het management (Jablonsky e.a., 1993; voor een samenvatting zie: Van Helden 1998, p. 19; Van der Meer-Kooistra, 1999, p. 82; Scapens, 1999, p. 645).

Algemeen wordt aangenomen dat de rol en de functie van de controller zich ontwikkelen van die van de 'corporate policeman' tot die van de 'business advocate'. Dit zou een verbreding van de controllersfunctie met zich meebrengen. Traas (1997, p. 43) waarschuwt voor het gevaar dat deze verbreding in zich bergt. Hij is van mening dat de primaire rol van de controller nog steeds die van financieel deskundige is. Door de steeds grotere aandacht voor niet-financiële kennis bij controllers raakt de vaktechnische kennis steeds meer op de achtergrond. Het gevaar houdt in dat de controller uitgroeit tot een functionaris die over het gehele spectrum van managementaangelegenheden (een beetje) mag meepraten, maar die op zijn eigen terrein van financieel-economisch management tekortschiet. Traas pleit dus voor een controllersprofiel dat het midden houdt tussen de 'corporate policeman' en de 'business advocate'. Wij zullen dit profiel aanduiden met de 'financieel adviseur'.

\section{Financieel adviseur}

Bij de financieel adviseur staat de financieel-economische expertise voorop. De financieel adviseur ondersteunt vanuit zijn eigen discipline de interne participanten. Ten opzichte van de 'corporate policeman' houdt de financieel adviseur zich meer bezig met het uitvoeren van beslissingscalculaties, het nadenken over het voor de organisatie meest geschikte waardeconcept (winst, aandeelhouderswaarde) en het leggen van causale relaties tussen activiteiten en kosten. We zien dus ook bij dit type controller dat de blik meer op de toekomst is gericht dan op het verleden. Dit betekent weliswaar een verbreding van de controllersfunctie, maar toch blijft de controller primair opereren vanuit zijn financieel-economische deskundigheid: de financieel adviseur denkt na over financiële prestatie-indicatoren en hij kan de besluitvormers vanuit financieel-economisch oogpunt ondersteunen (Traas, 1997).

Aan de hand van de literatuur kunnen we dus drie typen controllers onderscheiden, te weten: de 'corporate policeman', de financieel adviseur en de 'business advocate. Wanneer we ons concentreren op de rol van de controller, dan heeft de 'corporate policeman' vooral een administratieve en controlerende rol. De financieel adviseur vervult daarentegen de rol van ondersteuner. Hij beoordeelt alternatieven op hun financiële consequenties en verstrekt op basis daarvan adviezen. Ook de 'business advocate' ondersteunt het management met financiële analyses, maar hij denkt daarnaast met het management mee over de te volgen lijn. Bij dat laatste hanteert hij een breder dan een zuiver financieel perspectief.

\section{Mogelijke rollen}

De controller kan in het planning- en controlproces verschillende rollen vervullen. Bij de beschrijving van deze rollen zullen we gebruikmaken van inzichten die zijn ontleend aan Van Loon (1994, 1995). Van Loon beschrijft het verloop van de autonome ontwikkeling van de financieel-economische functie binnen organisaties in de loop der tijd. In deze ontwikkeling onderscheidt hij vijf stadia. In dit artikel zullen aan de hand van deze vijf stadia de mogelijke rollen van de controller in het planning- en controlproces worden besproken.

Het eerste stadium is het stadium van de non-planning. In dit stadium is de aanwezige financieel-economische deskundigheid beperkt. Er kan hier dan ook niet met recht worden gesproken van de aanwezigheid van een controller. Toch zullen er taken worden uitgevoerd die tot het taakgebied van de controller kunnen worden gerekend. Deze taken betreffen vooral het achteraf registreren van de financiële consequenties van de activiteiten. Aan de hand van de uit deze registratie afgeleide informatie kan eventueel control in financiële zin plaatsvinden. Er vindt echter geen planning in financiële zin plaats. Met andere woorden, er wordt niet systematisch gekeken naar de toekomstige financiële situatie. Vanwege het feit dat degene die de taken vervult die tot het taakgebied van de controller behoren vooral een administratieve rol vervult, past het stadium van de non-planning nog het beste bij de 'corporate policeman'. Zijn takenpakket is echter veel beperkter dan dat van de 'corporate policeman'.

Ook in het tweede stadium, het stadium van de financiële budgettering, is van een echt planningsproces in financiële zin nog geen sprake. Er is echter wel een budgetteringsproces. Daarbij worden de budgetten gebaseerd op financiële trends uit het verleden, die worden doorgetrokken naar de toekomst. De budgetten luiden dus volledig in financiële termen. Hierdoor kunnen ze zonder substantiële inbreng van de direct betrokkenen worden opgesteld door de controller. De budgetten geven per categorie de verwachte kosten en 
opbrengsten weer. Na goedkeuring van een budget mag niet meer worden geschoven tussen de categorieën. Het budget vormt zo een beperking voor de activiteiten van de organisatie. Bij deze vorm van budgettering past dus een zuiver financiële vorm van control, waarin men slechts de kosten en opbrengsten vergelijkt met de vooraf opgestelde normen. Bij een overschrijding van de normen gaat men niet naar de oorzaak hiervan zoeken. Het is in dit stadium dus de controller die de andere participanten vertelt of bepaalde activiteiten, gegeven het resterende budget, nog kunnen worden uitgevoerd. De controller legt andere interne participanten daarmee beperkingen op. We kunnen dus stellen dat de controller in het stadium van de financiële budgettering vooral de rol van 'corporate policeman' vervult.

Het derde stadium is dat van de jaarplanning. In dit stadium worden expliciete plannen opgesteld voor de activiteiten in het komende jaar. Deze plannen worden vertaald in financiële termen, hetgeen resulteert in de budgetten. Omdat het opstellen en vertalen van de plannen vraagt om inhoudelijke kennis, worden de budgetten in dit stadium opgesteld door de direct betrokkenen. De controller ondersteunt hen hierbij. Via de budgetten worden zowel inhoudelijke als financiële taakstellingen voor de budgethouders vastgelegd. Bij de control heeft men in dit stadium dan ook aandacht voor zowel de financiële als de inhoudelijke prestaties. Er wordt geprobeerd de oorzaken van eventuele afwijkingen tussen de geplande en de gerealiseerde financiële cijfers te achterhalen. Hiervoor worden onder andere de geplande en de gerealiseerde activiteiten vergeleken. Ook deze analyse vraagt om input van de direct betrokkenen. De controller kan hen hierbij wel ondersteunen. De controller vervult in dit stadium dus de rol van financieel adviseur.

Het volgende stadium is het stadium van de meerjarenplanning. In dit stadium wordt expliciet onderscheid gemaakt tussen enerzijds het bepalen van de omvang van de productiecapaciteit en anderzijds het bepalen van de benutting van de bestaande productiecapaciteit. Voor het planning- en controlproces heeft dit tot gevolg dat eerst een meerjarenplan wordt opgesteld, dat vervolgens als kader dient voor de jaarplannen en het budget. De controller ondersteunt de interne participanten bij het opstellen van plannen en budgetten en bij het analyseren van afwijkingen tussen geplande en gerealiseerde financiële cijfers. We zien dan ook dat de rol van de controller in dit stadium niet substantieel verschilt van zijn rol in het stadium van de jaarplanning. Ook in het stadium van de meerjarenplanning vervult de controller dus de rol van financieel adviseur.
Het laatste stadium is het stadium van de strategische planning. In dit stadium wordt er geanticipeerd op de toekomstige, onzekere marktsituatie. Op basis van een analyse van de sterke en zwakke punten van de organisatie en de kansen en bedreigingen vanuit de markt, wordt de meest wenselijke organisatiestrategie bepaald. Op deze manier stelt men vast welke (nieuwe) activiteiten de organisatie op lange termijn zal moeten uitvoeren, en wat de financiële consequenties daarvan zullen zijn. De uitkomsten van dit proces vormen een kader voor de plannen en de budgetten. De controller kan in dit stadium organisator en begeleider zijn van het proces dat leidt tot de totstandkoming van de strategische kaders. In dat geval heeft hij geen specifiek financieel-economisch profiel meer. De controller vervult dan de rol van 'business advocate'. Het is echter ook mogelijk dat een daarvoor opgerichte afdeling of projectgroep de organisatie en begeleiding van het proces verzorgt. In dat geval houdt de controller zich vooral bezig met het bieden van ondersteuning bij het vertalen van strategische kaders in plannen en budgetten en bij het opstellen van rapportages over de realisatie daarvan. Hij zal dan dus veel meer de rol van financieel adviseur vervullen. De uitkomsten van bovenstaande analyse worden samengevat in tabel 1 .

\begin{tabular}{|c|c|}
\hline Ontwikkelingsstadium & Rol controller \\
\hline Non-planning & 'Corporate policeman' (beperkt) \\
\hline Financiële budgettering & 'Corporate policeman' \\
\hline Jaarplanning & Financieel adviseur \\
\hline Meerjarenplanning & Financieel adviseur \\
\hline Strategische planning & $\begin{array}{l}\text { Financieel adviseur of } \\
\text { 'business advocate' }\end{array}$ \\
\hline
\end{tabular}

In paragraaf 4 zullen we, gebruikmakend van bovenstaande uitkomsten, onderzoeken welk type controller we kunnen verwachten in welk type organisatie.

\section{De invloed van het organisatietype op het type controller}

Tillema $(2000,2002)$ koppelt de ideeën van Van Loon aan een model voor de structuur van organisaties dat 
is ontwikkeld door Mintzberg $(1979,1993)$. Uit deze koppeling blijkt dat men verschillen tussen organisaties in het ontwikkelingsstadium van de gebruikte financiële instrumenten kan relateren aan verschillen tussen organisatietypen. Als er inderdaad een verband bestaat tussen het ontwikkelingsstadium van het gehanteerde financiële instrumentarium en het type organisatie, is het aannemelijk dat ook de rol van de controller afhankelijk is van het type organisatie. Daarom is het belangrijk om bij het onderzoeken van de rol van de controller in de praktijk, rekening te houden met het type organisatie waarin de controller werkzaam is. Om die reden gebruiken we de verschillende organisatietypen van Mintzberg als uitgangspunt bij het selecteren van organisaties voor het praktijkonderzoek. Allereerst zullen we echter voor elk van de organisatietypen bekijken welk controllersprofiel we op theoretische gronden kunnen verwachten. Daarbij zal verder worden gebouwd op inzichten die zijn ontleend aan Tillema $(2000,2002)$.

Het eerste organisatietype van Mintzberg is de eenvoudige structuur. Dit organisatietype komt met name voor bij kleine, jonge organisaties. Binnen dit type organisaties opereert het management van dag tot dag. Er is geen tijd voor en/of behoefte aan een planning van de toekomstige financiële situatie. Bovendien is het moeilijk om de toekomstige financiële situatie te plannen, omdat de eenvoudige structuur opereert in een dynamische omgeving. Het gevolg is dat alleen die financiële taken worden verricht die nodig zijn om te voldoen aan de verplichtingen op het gebied van de externe berichtgeving. Dit past bij het stadium van de non-planning. Vaak zien we dat de entrepreneur de weinige financiële taken zelf uitvoert. Er is bij dit organisatietype dus geen behoefte aan en plaats voor een controller. Om die reden zullen we geen controllersprofiel aan de eenvoudige structuur koppelen.

De machinebureaucratie komt vooral voor bij grote, oude organisaties die eenvoudige activiteiten uitvoeren en die opereren in een stabiele omgeving. Vanwege de stabiliteit van de omgeving hoeven de activiteiten van deze organisaties niet steeds te worden aangepast aan veranderde omstandigheden. Hierdoor zijn de activiteiten goed te plannen. Bovendien is vanuit het verleden bekend welke financiële consequenties verbonden zijn aan de uitvoering van de verschillende activiteiten. Dit maakt het betrekkelijk eenvoudig om de planning voor de verschillende functionele afdelingen te vertalen in budgetten. In de machinebureaucratie staat het streven naar efficiëntie centraal. Daarom is het ook waarschijnlijk dat budgetten op een dergelijke zorgvuldige manier tot stand komen. Elk budget bevat een nauwkeurig vastgelegde taakstelling voor zowel de financiële als de inhoudelijke prestaties. De stabiele omgeving en de eenvoud van de activiteiten maken ook control goed mogelijk. Managers kunnen snel inzicht verwerven in de uitgevoerde activiteiten en control zal om die reden waarschijnlijk bestaan uit het achterhalen van de oorzaken van de eventuele afwijkingen tussen de geplande en de gerealiseerde financiële situatie. De machinebureaucratie past dus bij de stadia van de jaarplanning en de meerjarenplanning. De controller opereert in deze stadia als financieel adviseur. Dit controllersprofiel is echter ook om een andere reden het meest voor de hand liggend. De machinebureaucratie kent namelijk een strikte arbeidsverdeling. Dit heeft tot gevolg dat de controller in de eerste plaats de rol van financieel-economisch deskundige op zich moet nemen.

De professionele bureaucratie doet zich voor bij organisaties waarvan de activiteiten dusdanig complex zijn dat alleen hoogopgeleiden deze kunnen uitvoeren. Deze hoogopgeleiden werken in grote mate zelfstandig en hebben veel zeggenschap over de uitvoering van hun activiteiten. De omgeving waarin de professionele bureaucratie opereert is stabiel. Dit maakt het mogelijk dat de professionele bureaucratie budgetten opstelt die vergelijkbaar zijn met de budgetten die de machinebureaucratie opstelt. In de professionele bureaucratie staat efficiëntie echter minder centraal dan in de machinebureaucratie. Dit zou tot gevolg kunnen hebben dat men minder hoge eisen stelt aan de budgetten. Het is zelfs mogelijk dat men in het geheel niet werkt met budgetten. Ten aanzien van de planning past de professionele bureaucratie dus bij de stadia van de non-planning, de financiële budgettering, de jaarplanning en de meerjarenplanning. Op basis daarvan verwachten we dat de controller in het planningsproces van de professionele bureaucratie optreedt als 'corporate policeman' of financieel adviseur. Ten aanzien van de control zal de controller echter niet kunnen optreden als financieel adviseur. Vanwege de complexiteit van de activiteiten van de professionele bureaucratie zal control in dit type organisaties moeilijk zijn. Het is voor buitenstaanders - zowel managers als controllers immers moeilijk om te beoordelen of afwijkingen tussen budget en realisatie te wijten zijn aan ongunstige externe omstandigheden of aan het gedrag van de professionals. De enigen die hier meer inzicht in kunnen geven zijn de professionals zelf, maar zij hebben er alle belang bij om afwijkingen toe te schrij- 
ven aan ongunstige externe omstandigheden. Het ligt daarom voor de hand dat control in de professionele bureaucratie beperkt blijft tot een vergelijking tussen de gerealiseerde en de gebudgetteerde kosten. Dit past bij het stadium van de financiële budgettering. In dit stadium opereert de controller als 'corporate policeman'.

De adhocratie komt voor bij organisaties die werken aan innovatieve oplossingen voor complexe, weinig gestructureerde problemen. Om deze problemen te kunnen oplossen worden kleine, multidisciplinaire projectgroepen geformeerd. Omdat deze projectgroepen steeds weer werken aan het oplossen van nieuwe problemen, is vaak onduidelijk welke activiteiten er in de toekomst precies zullen worden uitgevoerd. Dit maakt het plannen van de activiteiten erg moeilijk. Daar komt nog bij dat de financiële consequenties van de activiteiten waarvan al wél zeker is dat ze zullen worden uitgevoerd, vaak onbekend zijn doordat de organisatie nog geen ervaring heeft met deze activiteiten. Uit het bovenstaande kunnen we concluderen dat het voor de adhocratie moeilijk is om budgetten te baseren op plannen voor activiteiten. Voorzover de adhocratie met budgetten werkt, is het dus waarschijnlijk dat dit zuiver financiële budgetten zijn. In dat geval kan de rol van de controller beperkt blijven tot het stellen van financiële grenzen. Binnen deze grenzen geeft hij de projectgroepen dan alle ruimte om aan het creatieve proces te werken. Dit past bij het stadium van de financiële budgettering. Het is echter ook mogelijk dat de controller actief met de projectgroepen meedenkt wanneer keuzes omtrent de te volgen strategie moeten worden gemaakt. Dit laatste past bij het stadium van de strategische planning. Evenals bij de professionele bureaucratie bemoeilijkt de complexiteit van de activiteiten bij de adhocratie de control. Dit effect wordt nog versterkt door de dynamiek van de omgeving, die de onverwachte invloed van externe factoren waarschijnlijker maakt. De controller in de adhocratie kan daarom alleen control uitvoeren door de werkelijk gemaakte kosten te vergelijken met de toegestane kosten. Uiteraard is het ook mogelijk dat de adhocratie in het geheel niet werkt met budgetten en realisatieoverzichten. We kunnen dus stellen dat de adhocratie op het gebied van de control past bij de stadia van de non-planning en de financiële budgettering. In deze stadia ligt het voor de hand dat de controller optreedt als 'corporate policeman'. Op het gebied van de planning zou hij ook deze rol kunnen vervullen, maar hij zou ook kunnen optreden als 'business advocate'. Dit is immers de rol die we verwachten wanneer de controller actief betrokken is bij het bepalen van de strategie.

Kenmerkend voor organisaties die zijn te typeren als divisiestructuur, is dat zij bestaan uit meerdere divisies die centraal worden geleid door de directie op het hoofdkantoor. Elke divisie is in feite een kleinere autonome organisatie die op een aparte markt opereert. Binnen de divisiestructuur worden twee typen controllers onderscheiden: de divisiecontroller en de controller op het hoofdkantoor. De rol die beiden vervullen in het planning- en controlproces verschilt. Over de rol van de divisiecontroller kunnen geen algemene uitspraken worden gedaan. Zijn rol is namelijk afhankelijk van het organisatietype waartoe de divisie zelf behoort. Voor de hoofdkantoorcontroller kan wel een algemeen profiel worden geschetst. Daarbij moet onderscheid worden gemaakt tussen de twee taken die de hoofdkantoorcontroller vervult in het planning- en controlproces. De eerste taak omvat het leveren van een bijdrage bij het uitzetten van de organisatiestrategie en het vaststellen van de plannen. De hoofdkantoorcontroller zou in dit geval door middel van een portfolioanalyse in kaart kunnen brengen wat de sterke en zwakke punten van elk van de divisies zijn, en welke kansen en bedreigingen er voor deze divisies bestaan. Dit past bij het stadium van de strategische planning. De hoofdkantoorcontroller vervult dan de rol van 'business advocate' richting de directie. Het is echter ook mogelijk dat de portfolioanalyse wordt uitgevoerd door een speciaal daarvoor opgerichte afdeling of projectgroep. In dat geval vervult de controller richting de directie slechts de rol van financieel adviseur. De tweede taak van de hoofdkantoorcontroller omvat het kritisch bekijken van de door de divisies ingediende plannen en budgetten en het nauwlettend in de gaten houden van de werkelijke resultaten van de divisies. Bij het volgen van de werkelijke resultaten zal de aandacht van de hoofdkantoorcontroller vooral uitgaan naar de afwijkingen tussen de geplande en de gerealiseerde financiële resultaten. Hij heeft namelijk niet voldoende inzicht in de activiteiten van de divisies om de oorzaken van eventuele afwijkingen te kunnen achterhalen. Deze wijze van control past bij het stadium van de financiële budgettering. Richting de divisies vervult de hoofdkantoorcontroller dus de rol van 'corporate policeman'. De divisies zien hem ook vooral als controleur voor de directie. De hoofdkantoorcontroller richt zich immers op het veiligstellen van de belangen van het topmanagement en vindt het belangrijk dat de afgesproken normen worden gehaald. De uitkomsten van bovenstaande analyse worden samengevat in tabel 2 . 


\begin{tabular}{|c|c|}
\hline Organisatietype & Rol controller \\
\hline Eenvoudige structuur & Geen controller \\
\hline Machinebureaucratie & Financieel adviseur \\
\hline \multicolumn{2}{|c|}{ Professionele bureaucratie: } \\
\hline • Planning & $\begin{array}{l}\text { 'Corporate policeman' of } \\
\text { financieel adviseur }\end{array}$ \\
\hline - Control & 'Corporate policeman' \\
\hline \multicolumn{2}{|l|}{ Adhocratie } \\
\hline • Planning & $\begin{array}{l}\text { 'Corporate policeman' of } \\
\text { 'business advocate' }\end{array}$ \\
\hline - Control & 'Corporate policeman' \\
\hline \multicolumn{2}{|l|}{ Divisiestructuur: } \\
\hline - Richting directie & $\begin{array}{l}\text { Financieel adviseur of } \\
\text { 'business advocate' }\end{array}$ \\
\hline - Richting divisies & 'Corporate policeman' \\
\hline
\end{tabular}

Op theoretische gronden verwachten we dus in organisaties die met name kenmerken hebben van de professionele bureaucratie of de adhocratie, controllers die de beperkte rol van de 'corporate policeman' vervullen. Een vergelijkbare rol verwachten we ook in de divisiestructuur, maar dan alleen in het optreden van de hoofdkantoorcontroller richting de divisies. In organisaties die vooral kenmerken hebben van de machinebureaucratie, ligt het meer voor de hand dat de controller een uitgebreidere rol vervult, namelijk die van de financieel adviseur. Deze rol zou de controller ook kunnen vervullen in organisaties die vooral kenmerken hebben van de professionele bureaucratie of de divisiestructuur. Voor de professionele bureaucratie verwachten we deze rol echter alleen in het planningsproces; voor de divisiestructuur verwachten we deze rol alleen in het optreden van de hoofdkantoorcontroller richting de directie. De controller met de meest omvattende rol, die van de 'business advocate', verwachten we alleen aan te treffen in organisaties die met name kenmerken hebben van de adhocratie of de divisiestructuur. Voorwaarde is wel dat de controller een centrale rol vervult in het proces dat leidt tot de totstandkoming van de strategische kaders. Bovendien verwachten we deze rol in de adhocratie alleen in het planningsproces en in de divisiestructuur alleen in het optreden van de hoofdkantoorcontroller richting de directie. In paragraaf 5 bekijken we of deze theoretische verwachtingen overeenstemmen met onze waarnemingen in de praktijk.

\section{Resultaten van het praktijkonderzoek}

Om de theoretische verwachtingen aan de werkelijkheid te toetsen, hebben we een tiental ${ }^{5}$ controllers werkzaam bij verschillende typen organisaties - geïnterviewd. De meeste van deze controllers zijn werkzaam bij kleine en middelgrote organisaties. Over de hele linie varieerde de omvang van de deelnemende organisaties van 80 tot 1.500 werknemers. De organisaties waren afkomstig uit branches als de scheepsbouwindustrie, het onderwijs, de verpakkings-middelenindustrie en de consumptiegoederenindustrie. Het betrof daarbij zowel profit- als non-profitorganisaties. Voor de selectie van organisaties is gebruikgemaakt van de contacten die een van de auteurs in het kader van zijn advieswerkzaamheden met verschillende organisaties heeft. Deze auteur is overigens niet betrokken geweest bij het afnemen van de interviews. Het voornaamste criterium bij de selectie van organisaties was dat de organisaties samen een zo goed mogelijke afspiegeling vormden van de organisatietypen die door Mintzberg zijn onderscheiden.

Voor de interviews is gebruikgemaakt van semigestructureerde vragenlijsten. De betrokken controllers is gevraagd aan te geven of - en zo ja, hoe - in hun organisatie budgetten en plannen worden opgesteld. Daarnaast is hen gevraagd naar de vorm van control die in hun organisatie wordt toegepast. Bovendien moesten de controllers aangeven wat hun rol is bij het opstellen van budgetten en plannen en bij het uitvoeren van control. Om de kans op sociaal wenselijke antwoorden te verkleinen, is de controllers eerst gevraagd een algemene schets te geven van planning en control in hun organisatie. Pas daarna kwam hun eigen rol aan de orde. Bovendien is het gebruik van de kwalificaties 'corporate policeman', financieel adviseur en 'business advocate' en van daarmee vergelijkbare kwalificaties uitdrukkelijk vermeden. Tot slot hebben de controllers meer algemene informatie verschaft over de activiteiten en de omgeving van de organisatie waarin zij werkzaam zijn. Deze informatie is gebruikt om te bepalen tot welke organisatietypen de organisaties behoren. De uiteindelijke classificatie van een organisatie is gebaseerd op het gemiddelde opleidingsniveau van de medewerkers op de werkvloer en de mate waarin deze medewerkers beslissingsbevoegdheid hebben, de mate waarin in procedures is vastgelegd hoe de werkzaamheden op de werkvloer moeten worden uitgevoerd, de mate waarin deze werkzaamheden aan verandering onderhevig zijn, de wijze waarop 
de organisatie is gegroepeerd in organisatorische eenheden (op een functionele basis, op een marktbasis of in projectteams) en de vraag of de organisatie in min of meer autonome eenheden is opgesplitst.

In tabel 3 zijn de resultaten van het praktijkonderzoek afgezet tegen de theoretische verwachtingen zoals die zijn geformuleerd in paragraaf 4 . Voor de professionele bureaucratie geldt dat bij de typering van de rol van de controller onderscheid is gemaakt tussen enerzijds zijn rol in het planningsproces en anderzijds zijn rol in het controlproces. Voor de divisiestructuur geldt dat bij de typering van de rol van de controller onderscheid is gemaakt tussen zijn rol richting de directie en zijn rol richting de divisies. In de tabel is steeds tussen haakjes aangegeven hoe vaak een bepaald type organisatie en een bepaald type controller in de praktijk zijn angetroffen. Vanwege het feit dat voor zowel de professionele bureaucratie als de divisiestructuur onderscheid wordt gemaakt tussen twee rollen, is het aantal getypeerde controllers groter dan het aantal getypeerde organisaties. Aangezien geen van de aan het onderzoek deelnemende bedrijven als adhocratie te typeren is, ontbreken in deze tabel gegevens omtrent de adhocratie.

Een van de bij het onderzoek betrokken organisaties heeft vooral kenmerken van de eenvoudige structuur.

\begin{tabular}{|c|c|c|}
\hline \multicolumn{3}{|c|}{$\begin{array}{l}\text { Tabel 3. De rol van de controller in de verschillende } \\
\text { organisatietypen: theorie en praktijk }\end{array}$} \\
\hline Organisatietype & $\begin{array}{l}\text { Rol controller: } \\
\text { theorie }\end{array}$ & $\begin{array}{l}\text { Rol controller: } \\
\text { praktijk }\end{array}$ \\
\hline $\begin{array}{l}\text { Eenvoudige } \\
\text { structuur (1) }\end{array}$ & Geen controller & Geen controller (1) \\
\hline $\begin{array}{l}\text { Machine- } \\
\text { bureaucratie (2) }\end{array}$ & Financieel adviseur & $\begin{array}{l}\text { Financieel adviseur (1) } \\
\text { 'Business advocate' (1) }\end{array}$ \\
\hline \multicolumn{3}{|l|}{$\begin{array}{l}\text { Professionele } \\
\text { bureaucratie (3) }\end{array}$} \\
\hline • Planning & $\begin{array}{l}\text { 'Corporate policeman' } \\
\text { Financieel Adviseur }\end{array}$ & Financieel adviseur (3) \\
\hline - Control & 'Corporate policeman' & Financieel adviseur (3) \\
\hline \multicolumn{3}{|l|}{ Divisiestructuur (4) } \\
\hline - Richting directie & $\begin{array}{l}\text { Financieel adviseur } \\
\text { 'Business advocate' }\end{array}$ & $\begin{array}{l}\text { Financieel adviseur (2) } \\
\text { 'Business advocate' (2) }\end{array}$ \\
\hline - Richting divisies & 'Corporate policeman' & $\begin{array}{l}\text { 'Corporate policeman' (2) } \\
\text { 'Business advocate' (2) }\end{array}$ \\
\hline
\end{tabular}

Voor deze organisatie blijkt de theoretische verwachting dat men in de eenvoudige structuur geen aparte controllersfunctie aan zal treffen, juist te zijn. Het management van deze organisatie kijkt niet systematisch naar de toekomstige situatie: het beleid komt tot stand door ad-hocbeslissingen, waarbij intuïtie en praktische overwegingen een belangrijke rol spelen, en de planning blijft beperkt tot het opstellen van de wekelijkse productieplanningen. De weinige financiële taken die in deze organisatie worden uitgevoerd, worden door een van de directieleden zelf uitgevoerd. Wanneer de organisatie aanvullende financiële expertise nodig heeft, wordt een externe adviseur in de arm genomen. Ook de verwachting dat wanneer een eenvoudige structuur doorgroeit, er wel een controller zal worden aangetrokken, blijkt in deze organisatie op te gaan. De geïnterviewde gaf namelijk aan dat een aparte controllersfunctie zal worden gecreëerd indien de huidige groei zich zal doorzetten.

Twee van de deelnemende organisaties zijn te typeren als een machinebureaucratie. Een van deze organisaties heeft in vrijwel alle opzichten de kenmerken van een machinebureaucratie. Bij deze organisatie komt de praktijksituatie ook overeen met de theoretische verwachtingen: de controller vervult in het planningen controlproces de rol van financieel adviseur. De andere organisatie is weliswaar in grote lijnen ook te typeren als een machinebureaucratie, maar de financiële huishouding van deze organisatie is nog weinig gestructureerd. Zo werden er tot voor kort geen plannen voor de activiteiten opgesteld en vindt er tot op heden geen control plaats. Momenteel is men echter wel druk bezig om orde op zaken te stellen. In deze organisatie is de controller het beste te typeren als 'business advocate'. De controller besteedt veel tijd aan het op orde krijgen van de financiële huishouding, maar houdt zich ook bezig met strategische vraagstukken en met de inrichting van de organisatie. Zijn inhoudelijke bijdrage op financieel gebied is echter zeer beperkt. Alhoewel dit controllersprofiel niet overeenkomt met de theoretische verwachting, is de aanwezigheid van een controller met dit profiel toch goed te verklaren. Deze organisatie beschikt namelijk nog niet over de structuren die nodig zijn om de controller een rol als adviseur en ondersteuner te kunnen laten vervullen. De meeste aandacht van de controller gaat op dit moment daarom uit naar het opzetten van deze structuren. Dit vraagt om een breder gezichtsveld dan een zuiver financieel-economisch gezichtsveld.

Van de in het onderzoek betrokken organisaties kunnen drie worden beschouwd als een professionele 
bureaucratie. Voor de analyse van de rol van de controller in de professionele bureaucratie moet onderscheid worden gemaakt tussen twee takgebieden. Voor het taakgebied van de planning komen theorie en praktijk overeen. In de praktijk stellen de direct betrokkenen namelijk zelf hun budgetten op. De controller gedraagt zich hierbij als financieel adviseur. Hoewel we op basis van de theorie ook een controller hadden kunnen verwachten die bij de planning opereert als 'corporate policeman', treffen we deze bij de onderzochte organisaties niet aan. Voor het taakgebied van de control komen praktijk en theorie niet overeen. De theorie voorspelt namelijk dat de controller zich hier als 'corporate policeman' opstelt, maar in de praktijk gaven de controllers aan de rol van financieel adviseur te vervullen. In de praktijk lijkt de controller van de professionele bureaucratie zich in het planning- en controlproces dus vooral te gedragen als financieel adviseur die desgewenst adviseert en ondersteunt, in plaats van als financieel expert die de interne participanten beperkingen oplegt.

Vier van de geïnterviewde controllers zijn aan te merken als hoofdkantoorcontrollers in een divisiestructuur ${ }^{6}$. De theoretische verwachting dat de rol van dit type controller tweeledig is, blijkt in de praktijk inderdaad uit te komen. Deze controllers vervullen namelijk richting de directie een andere rol dan richting de divisies. Op grond van de theorie verwachtten we dat de hoofdkantoorcontroller richting de directie als financieel adviseur of 'business advocate' optreedt. In de praktijk blijken de hoofdkantoorcontrollers in twee organisaties inderdaad de rol van 'business advocate' te vervullen. Maar hierbij moet de kanttekening worden geplaatst dat deze controllers tevens deel uitmaken van de directie. Een zuiver beeld van deze controllers is daardoor moeilijk te verkrijgen. Naast hun staffunctie voeren zij immers tevens een lijnfunctie uit. De andere twee controllers zijn te typeren als financieel adviseur. De directie vindt hun financiële advies belangrijk, maar van een bredere, meer leidende rol is geen sprake. De divisies zien deze laatste twee controllers als 'corporate policeman'. Dit komt overeen met de theorie. In hun ogen behartigen de controllers de belangen van de directie en stellen zij zich op als controleur van de cijfers. In de organisaties waarin de controllers naast een staffunctie ook een lijnfunctie vervullen, worden de controllers door de divisies daarentegen niet als controleur gezien, maar als een ondersteuner en leidinggevende. Dit sluit het beste aan bij het profiel van de 'business advocate'. Op grond van de theorie hadden we niet verwacht dit controllersprofiel aan te treffen bij het optreden van de hoofdkantoorcontroller richting de divisies.
Samengevat kunnen we dus stellen dat er weliswaar overeenkomsten zijn tussen de theorie en de praktijk, maar dat er geen overtuigend bewijs bestaat voor de door ons veronderstelde relatie tussen het organisatietype en de rol van de controller. Naar aanleiding van dit resultaat vindt in paragraaf 6 een discussie plaats. Daarbij wordt tevens ingegaan op de factoren die wel van invloed zijn gebleken op de rol van de controller.

\section{Discussie}

In de literatuur blijft de discussie over de noodzakelijk geachte en verwachte verandering van de rol van de controller voortduren. Desondanks lijkt het erop dat deze rol in de Nederlandse praktijk voorlopig niet zo sterk verandert als wel in de literatuur wordt gesuggereerd. De uitkomsten van ons praktijkonderzoek (zie tabel 3) suggereren namelijk dat in de praktijk het type van de financieel adviseur nog het meeste voorkomt. Dit lijkt erop te duiden dat veel controllers nog steeds een voornamelijk financieeleconomische functie bekleden en dat hun rol vooral bestaat uit het ondersteunen en adviseren van interne participanten. Daarmee worden de uitkomsten van de personeelsadvertentieonderzoeken van Van Helden (1998) en Van Helden en Rutten (2000), die reeds in de inleiding aan de orde kwamen, bevestigd. Tabel 3 suggereert overigens wel dat ook het in de literatuur gewenste en verwachte type van de 'business advocate' in de praktijk regelmatig voorkomt. Bij de aan het onderzoek deelnemende organisaties doet dit type zich echter met name voor indien sprake is van een gecombineerde lijn/staffunctie voor de controller. De meeromvattende rol houdt hier dus geen controller met een meeromvattende rol in, maar een controller die naast zijn staffunctie tevens een lijnfunctie vervult. Vanuit deze lijnfunctie heeft hij een meeromvattende rol. In de literatuur wordt een situatie waarin de controller tevens lid is van het managementteam ook wel gezien als het eindpunt van het veranderingsproces van de controllersfunctie (zie bijvoorbeeld Granlund en Lukka, 1998, p. 187). Voor de door ons onderzochte organisaties geldt echter dat zij alleen om praktische redenen hebben gekozen voor een controller met een gecombineerde lijn/staffunctie.

Uit het onderzoek is niet duidelijk gebleken dat de rol van de controller wordt beïnvloed door het type organisatie waarin de controller werkzaam is. Alleen voor de divisiestructuur zien we duidelijke verschillen tussen de rol van de hoofdkantoorcontroller richting de directie en zijn rol richting de divisies. Voor de directie vervult de hoofdkantoorcontroller vooral de rol van financieel adviseur; voor de divisies vervult 
hij vooral de rol van 'corporate policeman'. Ook Granlund en Lukka (1998, p. 199) merken op dat de rol van de controller in de divisiestructuur tweeledig is. Zij signaleren dat de controller van een divisie in zijn communicatie met de eigen divisie vooral optreedt als bedrijfsgeoriënteerd lid van het managementteam en als financieel adviseur, terwijl hij in zijn communicatie met andere leden van de financieel-economische functie vooral optreedt als de lokale bewaker die ervoor zorgt dat de belangen van het hoofdkantoor niet uit het oog worden verloren.

Uit het onderzoek zijn meerdere factoren naar voren gekomen die wel van invloed zijn op de rol van de controller in een organisatie. Zo zijn in de eerste plaats de persoonlijke voorkeuren van de controller bepalend. Niet alle controllers hebben namelijk de ambitie om hun financieel-economische adviesveld te verbreden. Meerdere geïnterviewde controllers gaven juist aan dat zij hun adviesveld bewust beperkt houden tot hun eigen vakgebied. Daarnaast lijken ook assertiviteit en interesses de rol van de controller te bepalen. Bovendien zijn opleiding en ervaring van invloed op de rol van de controller. Tot slot kan de rol van de controller ook worden beïnvloed door de financiële ruimte die een organisatie heeft. Deze waarnemingen sluiten aan bij de constatering van Van der Meer-Kooistra (1998), die reeds in de inleiding werd genoemd, dat de rol en de functie van de controller onder andere verband houden met persoonsgebonden kenmerken en met de ontstaansreden van de controllersfunctie.

De meest opvallende afwijkingen tussen onze theoretische verwachtingen en onze empirische bevindingen treden op voor de professionele bureaucratie. Bij dit organisatietype verwachtten we, naast de financieel adviseur, ook de 'corporate policeman' aan te treffen. De voor dit organisatietype geïnterviewde controllers gaven echter aan zowel bij de planning als bij de control op te treden als financieel adviseur. Voor het taakgebied van de control is dit zelfs in strijd met onze theoretische verwachtingen. Meer specifiek verwachtten we dat bij de control de rol van de controller eruit zou bestaan dat hij controleert of het budget niet wordt overschreden. In de praktijk blijkt de controller daarentegen ondersteuning te bieden bij het in kaart brengen van de oorzaken van budgetoverschrijdingen. Het is echter belangrijk om hierbij twee kanttekeningen te plaatsen. In de eerste plaats gaven de geïnterviewde controllers - conform onze verwachtingen - aan dat zij bij de analyse van budgetoverschrijdingen in belangrijke mate moeten vertrouwen op de oorzaken die de professionals aangeven. In die zin zal de ondersteuning die een controller kan bieden, gering zijn. In de tweede plaats is het belangrijk om in het oog te houden dat onze empirische bevindingen volledig zijn gebaseerd op de visie die controllers hebben op hun eigen rol. Van Helden (1998, p. 19) verwijst echter naar onderzoek waaruit blijkt dat waar de controller veelal geneigd is zichzelf te typeren als 'business advocate', het management meer geneigd is de controller te typeren als 'corporate policeman'. In ons geval zou dit onder andere een vertekend beeld kunnen opleveren van de rol van de controller in de professionele bureaucratie.

In grote lijnen bevestigt ons onderzoek dus het beeld dat we hadden op basis van het op beperkte schaal uitgevoerde onderzoek naar de rol en de functie van de controller in de Nederlandse praktijk. Het biedt echter weinig aanknopingspunten voor de door ons veronderstelde relatie tussen de rol van de controller en het type organisatie waarin hij werkzaam is. Desondanks is het te vroeg om deze mogelijke relatie als niet interessant te beschouwen. Enerzijds waren onze bevindingen gebaseerd op het geringe aantal van tien bruikbare waarnemingen. Anderzijds hebben we organisatietypen onderscheiden op basis van een theorie van Mintzberg die stamt uit 1979. Daarmee zou de gebruikte theorie te gedateerd kunnen zijn om relevant te zijn voor onderzoek naar de controllersfunctie in hedendaagse organisaties. Zo veronderstelt Mintzberg dat de voor dit onderzoek meest relevante organisatietypen - de machinebureaucratie, de professionele bureaucratie en de divisiestructuur - vooral voorkomen of het beste werken in een stabiele omgeving. De hedendaagse technologische ontwikkelingen en toenemende internationale concurrentie zorgen er echter voor dat in vrijwel geen enkele branche nog sprake is van een stabiele omgeving. Het is daarom interessant om te onderzoeken of andere, meer moderne organisatietheorieën meer inzicht kunnen geven in de rol van de controller in de praktijk. Op basis van ons onderzoek kunnen we wel duidelijke richtlijnen geven voor dit en ander onderzoek naar de rol en de functie van de Nederlandse controller. Zo laat ons onderzoek zien dat het noodzakelijk is om onderscheid te maken tussen controllers die een zuivere staffunctie vervullen en controllers die om praktische redenen naast hun staffunctie ook een lijnfunctie vervullen. Bovendien is het van belang gebleken om onderscheid te maken tussen de rol van de controller richting het eigen management en zijn rol richting een hoger of lager organisatieniveau. Tot slot bleek het belangrijk om onderscheid te maken tussen de rol van de controller zoals de controller die zelf ziet en de rol van de controller zoals het manage- 
ment die ziet. Gegeven deze bevindingen kunnen we stellen dat er een breed en interessant terrein openligt voor verder onderzoek naar de ontwikkeling van de controller in de Nederlandse praktijk.

\section{Literatuur}

Bos, K.Y. en O.C. van Leeuwen, (1999), De toekomst van de financiële functie: wil de laatste het licht uit doen?, in: Tijdschrift Financieel Management, vol. 19, maart/april, pp. 9-18.

Burns, J., R. Scapens en S. Turley, (1996), Some further thoughts on the changing practice of management accounting, in: Management Accounting, vol. 74, no. 9, pp. 58-60.

Granlund, M. en K. Lukka, (1998), Towards increasing business orientation: finnish management accountants in a changing cultural context, in: Management Accounting Research, vol. 9, no. 2, pp. 185-211.

Helden, G.J. van, (1997), Management-accountinggoeroes over de toekomst van de controller, in: Tijdschrift Financieel Management, vol. 17, maart/april, pp. 81-87

Helden, G.J. van, (1998), De controller van de toekomst: over de kloof tussen droom en werkelijkheid, in: Tijdschrift Financieel Management, vol. 18, november/december, pp. 14-22.

Helden, G.J. van, en M.P.-J. Rutten, (2000), Wat zeggen personeelsadvertenties over het profiel van de controller in non-profitorganisaties?, in: Overheidsmanagement, vol. 13, no. 5, pp. 122-125.

Institute of Management Accountants (IMA), (1996), The practice analysis of management accounting, IMA Publication 240-96313, IMA, Montvale.

Jablonsky, S.F., P.J. Keating en J.B. Heian, (1993), Business advocate or corporate policeman? Assessing your role as a financial executive, Financial Executives Research Foundation, New Jersey.

Loon, P.J.J.M. van, (1994), Dynamiek in de financieel-economische functie, in: G.J van Helden, J.C.E. van Kollenburg, P.J.J.M van Loon (redactie), Financiële aspecten van non-profit management, Samson, Alphen aan den Rijn, pp. 21-43.

Loon, P.J.J.M. van, (1995), Financieel en economisch management: een proeve van beschrijving, advisering en onderzoek, in: Maandblad voor Accountancy en Bedrijfseconomie, vol. 69, september, pp. 496-508.

Meer-Kooistra, J. van der, (1998), De controller als criticus, ondersteuner en inspirator van het management, inaugurele rede, Rijksuniversiteit Groningen.

Meer-Kooistra, J. van der, (1999), Ontwikkelingen in de controllersfunctie, in: Tijdschrift Financieel Management, vol. 19, juli/augustus, pp. 73-85.

Mintzberg, H., (1979), The structure of organizations, Prentice-Hall, Englewood Cliffs.

Mintzberg, H., (1993), Structures in fives: designing effective organizations, 2de druk, Prentice-Hall, Englewood Cliffs.

Scapens, R.W., (1999), Broadening the scope of management accounting: from a micro-economic to a broader business perspective, in: Maandblad voor Accountancy en Bedrijfseconomie, vol. 73, december, pp. 638-649.

Tillema, S., (2000), Veranderingen in financiële instrumenten binnen organisaties, in: Maandblad voor Accountancy en Bedrijfseconomie, vol. 74, no. 4, pp. 86-99.
Tillema, S., (2002), Sophistication of accounting instruments: An integrated framework for explaining the use of simple and advanced management accounting information, dissertatie, Rijksuniversiteit Groningen.

Traas, L., (1997), Management accountants/controllers onder de maat?, in: Tijdschrift Financieel Management, vol. 17, juli/augustus, pp. 43-45.

\section{Noten}

1 Dit artikel is gebaseerd op de afstudeerscriptie die Drs. F.L. Riedijk schreef in het kader van haar inmiddels afgeronde studie Economie aan de Rijksuniversiteit Groningen.

2 Voor een overzicht van deze literatuur, zie: Van Helden $(1997,1998)$ en Van der Meer-Kooistra (1998, 1999). Ook Bos en Van Leeuwen (1999) geven een interessante visie op de ontwikkeling van de rol en de functie van de controller.

3 Zie ook: Scapens (1999)

4 Tillema $(2000,2002)$ brengt de adhocratie alleen in verband met de stadia van de non-planning en de financiële budgettering. Zij concentreert zich echter niet op controllerstypen, maar op financiële instrumenten. Deze instrumenten beschouwt zij onder meer als geavanceerd indien ze toekomstgerichte financiële informatie combineren met toekomstgerichte niet-financiële informatie. Vanwege de problemen die de adhocratie ervaart bij het produceren van toekomstgerichte financiële informatie, is het aannemelijk dat de financiële instrumenten binnen dit organisatietype weinig geavanceerd zijn. Dit sluit echter niet uit dat de controller wel een geavanceerde rol aanneemt. De meest geavanceerde rol, die van de 'business advocate', houdt immers in dat de controller niet alleen financiële adviezen geeft, maar ook vanuit een breder perspectief met het management meedenkt.

5 Feitelijk hebben we de controllers van elf organisaties geïnterviewd. Een van deze organisaties kon echter niet worden getypeerd als een van de door ons onderscheiden organisatietypen. De waarnemingen voor deze organisatie zijn buiten de analyse gehouden.

6 Naast hoofdkantoorcontrollers zijn er in het onderzoek ook divisiecontrollers betrokken. Hun rol wordt echter besproken bij de behandeling van het organisatietype waaronder de divisies zelf - los van hun plaats in de divisiestructuur - kunnen worden gerangschikt. 